\title{
Possible Escape of a Recombinant Isolate of Potato virus $Y$ by Serological Indexing and Methods of its Detection
}

\author{
R. P. Singh, Agriculture and Agri-food Canada, Potato Research Centre, P.O. Box 20280, Fredericton, NB, E3B 4Z7, \\ Canada; D. L. McLaren, AAFC, Brandon Research Centre, P.O. Box 1000A, R.R. 3, Brandon, MB R7A 5Y3, Can- \\ ada; X. Nie, Agriculture and Agri-food Canada, Potato Research Centre, P.O. Box 20280, Fredericton, NB, E3B 4Z7, \\ Canada; and M. Singh, Agricultural Certification Services, 1030 Lincoln Road, Fredericton, NB, E3B 8B7, Canada
}

\begin{abstract}
Singh, R. P., McLaren, D. L., Nie, X., and Singh, M. 2003. Possible escape of a recombinant isolate of Potato virus $Y$ by serological indexing and methods of its detection. Plant Dis. $87: 679-685$.

Surveys of commercial and seed potato fields for virus diseases (1998 to 2002) in Manitoba established that Potato virus $Y$ (PVY) is of concern in seed potato production. To determine the prevalence of PVY strains, PVY-infected tubers identified by reverse transcription-polymerase chain reaction (RT-PCR) from surveys (2000 to 2001) were grown for symptom expression and strain characterization by strain-specific RT-PCR, bioassays, and serological assays. Of the samples collected (2000 to 2001) and tested by RT-PCR, 4.0\% contained PVY. Further analysis of the PVY-positive samples by a duplex RT-PCR facilitating the simultaneous detection of common $\left(\mathrm{PVY}^{\mathrm{O}}\right)$ and tobacco veinal necrosis strains $\left(\mathrm{PVY}^{\mathrm{N} / \mathrm{NTN}}\right)$ indicated that $37.5 \%$ contained $\mathrm{PVYO}^{\mathrm{O}}$ and $63.5 \%$ contained $\mathrm{PVY}^{\mathrm{N}}$-type isolates. Analysis of the PVY ${ }^{\mathrm{N}}$-type samples using three monoclonal antibodies (MAbs) showed that all reacted with only the PVYO MAbs and not with the PVYN-specific MAb. Partial nucleotide sequences of both ends of PVY-RNA showed that the PVYN-type isolates resembled those reported in 1996 from Manitoba. These isolates are designated as PVYN:O. In view of the increased incidence of PVYN:O in one production area, seed tubers imported from other provinces of Canada and the neighboring United States were analyzed for PVY ${ }^{\mathrm{N}: O}$. The PVY $\mathrm{P}^{\mathrm{N}: \mathrm{O}}$ was detected in imported seeds from Minnesota, Montana, and North Dakota.
\end{abstract}

Potato virus $Y$ (PVY) is the type-species of genus Potyvirus, a positive strand monopartite RNA virus that infects many important food and vegetable crops worldwide including pepper, potato, tobacco, and tomato (28). Several strain groups of PVY are recognized on the basis of symptoms in naturally infected potatoes (Solanum tuberosum) and tobacco (Nicotiana tabacum) $(7,15)$. The common strain $\left(\mathrm{PVY}^{\mathrm{O}}\right)$ induces mild to severe mosaic and leaf drop streaks in potato, and systemic mottle in tobacco. The tobacco veinal necrosis group $\left(\mathrm{PVY}^{\mathrm{N}}\right)$ induces very mild mottling in most potato cultivars with occasional leaf necrosis in some $(3,15)$ and induces severe systemic necrosis of leaf veins and petioles in tobacco (7). The PVY ${ }^{\mathrm{NTN}}$ subgroup strains of PVY ${ }^{\mathrm{N}}$ causing potato tuber necrotic ringspot disease induce chlorotic mottle to mosaic symptoms in potato plants and superficial to deeply sunken necrotic rings in tubers, and the

Corresponding author: R. P. Singh

E-mail: singhr@agr.gc.ca

Accepted for publication 22 January 2003.

Publication no. D-2003-0331-02R

This article is in the public domain and not copyrightable. It may be freely reprinted with customary crediting of the source. The American Phytopathological Society, 2003. veinal necrosis symptoms in tobacco (17). Some partially characterized strains, including recombinants of $\mathrm{PVY}^{\mathrm{N}}$ and $\mathrm{PVY}^{\mathrm{O}}$ $(2,4,15,20)$, the $\mathrm{PVY}^{\mathrm{C}}$ strains which induce stipple streak symptoms in potato cultivar bearing the $N c$ gene, and the $\mathrm{PVY}^{\mathrm{Z}}$ strains which overcome the resistance genes against both PVY ${ }^{\mathrm{O}}$ and $\mathrm{PVY}^{\mathrm{C}}(12,15)$, also exist.

$\mathrm{PVY}^{\mathrm{O}}$ and the $\mathrm{PVY}^{\mathrm{N}}$ strains that infect potato and tobacco have been known for seven decades (39). However, the general group of $\mathrm{PVY}^{\mathrm{N}}$, including $\mathrm{PVY}^{\mathrm{NTN}}(15,17)$ (referred to here as $\mathrm{PVY}^{\mathrm{N} / \mathrm{NTN}}$ ), and other possible recombinants of $\mathrm{PVY}^{\mathrm{O}}$ and $\mathrm{PVY}^{\mathrm{N}}$ including $\mathrm{PVY}^{\mathrm{Z}}(2,12)$, isolate Wilga (4), and the isolates L-56 and L-136 $(20,21)$ (the latter designated as $\mathrm{PVY}^{\mathrm{N}: \mathrm{O}}$ [25]) have been recently recognized. In addition to the increasing number of strains, the PVY ${ }^{\mathrm{N} / \mathrm{NTN}}$ group has been assigned to European $(\mathrm{Eu})$ $\mathrm{PVY}^{\mathrm{N} / \mathrm{NTN}}$ and North American (NA) PVYN/NTN geographical subgroups (24). The diagnosis of $\mathrm{PVY}^{\mathrm{N} / \mathrm{NTN}}$ strains has become complex due to the incidence of mixed infections $(27,41,42)$ and increasing numbers of strains and substrains (24). Bioassay and serological and molecular assays may be required to provide conclusive identification of strains (36). The complex assay requirement precludes large-scale testing of seed tubers to prevent unwanted strains in planting material.

PVY strains have the potential to significantly reduce potato yield and quality, and therefore, PVY-free potato seed is required by potato certification programs in many countries (38). Although careful sanitary measures reduce the infection and spread of $\mathrm{PVY}^{\mathrm{O}}$, a minimal number of $\mathrm{PVY}^{\mathrm{O}}$-infected tubers in a seed lot can be tolerated. In contrast, it is a common practice in North America to limit the importation or introduction of seed potatoes from areas where even a low percentage of potatoes may be infected with $\operatorname{PVY}^{\mathrm{N}}(1,31,33)$. Consequently, the North American Plant Protection Organization (NAPPO) approved a set of recommendations for $\mathrm{PVY}^{\mathrm{N}}$ risk management, which included a panel of three monoclonal antibodies (MAbs) with differing specificity (see the NAPPO website) to screen seed potatoes for $\mathrm{PVY}^{\mathrm{N}}$.

Accurate and speedy diagnosis of PVY and its strains is an important consideration in the effective management of the potato seed crop. Diagnosis based on bioassay is generally reliable but time-consuming $(29,36)$. Enzyme-linked immunosorbent assay (ELISA) is rapid but relies on strainspecific antibodies, with separate tests for different antibodies, and the need for sprouted rather than dormant tubers $(11,37)$. However, false positive results can occur with ELISA, especially for the $\mathrm{PVY}^{\mathrm{N}: \mathrm{O}}$ isolates, which may share $\mathrm{PVY}^{\mathrm{O}}$ like coat protein but cause $\mathrm{PVY}^{\mathrm{N}}$-like symptoms in tobacco $(20,21)$.

Reverse transcription-polymerase chain reaction (RT-PCR) is a powerful tool for potato virus diagnosis $(22,23,32,41)$. The P1 gene of the PVY genome has been proposed as the most variable region among the potyviruses (8), including the various strains of PVY (18). For example, by targeting the P1 gene, a 3-primer system can differentiate between the Eu-type $\mathrm{PVY}^{\mathrm{N} / \mathrm{NTN}}$ and NA-PVY ${ }^{\mathrm{N} / \mathrm{NTN}} \quad(36,43)$ Similarly, Eu-type, and NA-type PVYN/NTN can be distinguished from all other PVY ${ }^{N}$ and PVY ${ }^{\mathrm{NTN}}$ isolates in a competitive RTPCR based on sequence variation in the P1 gene $(24,25)$. However, a multiplex RTPCR protocol, which would facilitate simultaneous detection and differentiation of both $\mathrm{PVY}^{\mathrm{O}}$ and $\mathrm{PVY}^{\mathrm{N}}$, including the recombinant $\left(\mathrm{PVY}^{\mathrm{N}: \mathrm{O}}\right)$ strains, may be of practical use for large-scale tests to manage $\mathrm{PVY}^{\mathrm{N}}$ in seed certification programs. In this study, the distribution of the $\mathrm{PVY}^{\mathrm{N}: \mathrm{O}}$-like isolates and their possible sources of introduction in Manitoba and 
their detection using a duplex RT-PCR, which simultaneously differentiates between the $\mathrm{PVY}^{\mathrm{O}}$ group and the $\mathrm{PVY}^{\mathrm{N} / \mathrm{NTN}}$ group, is described.

\section{MATERIALS AND METHODS}

Potato samples and symptom expression. In Manitoba, 6,201 tubers from 34 fields (2000) and 2,383 tubers from 12 fields (2001) were collected randomly and examined for tuber necrosis symptoms. Both seed and processing potato fields were sampled. In 2001, 228 leaf samples biased in favor of mosaic symptoms were also collected from 20 fields. The leaf and tuber samples were first tested for PVY by a duplex RT-PCR devised for the simultaneous detection of Potato leafroll virus (PLRV) and PVY (34), and the samples identified as infected by PVY were used for determination of PVY strains.

One seed piece from each PVY-infected tuber was planted in a $15-\mathrm{cm}$ plastic pot containing a soil mix. Plants were grown in a greenhouse with $12 \mathrm{~h}$ light $\left(90 \mu \mathrm{m}^{-2} \mathrm{~s}^{-1}\right)$ at 15 to $18^{\circ} \mathrm{C}$ to optimize virus symptoms (29). Symptoms were recorded every month for 3 months. Progeny tubers were examined for tuber necrosis symptoms.

Search for $\mathrm{PVY} \mathrm{N}^{\mathrm{N}: \mathrm{O}}$ in potato regions. To determine sources of $\mathrm{PVY}^{\mathrm{N}: \mathrm{O}}$ introduction into Manitoba, where potato seed is imported from a number of Canadian provinces (Alberta, British Columbia, Saskatchewan) and the neighboring United States (Minnesota, Montana, North Dakota), tubers and leaves were tested. Seed tubers were collected prior to planting in late April and early May of 2002, and leaves were collected in the first 2 weeks of July 2002. Except for Montana, two seed lots from each imported and five domestic seed sources were selected. One seed lot was selected from Montana. A random sample of 180 to 210 seed tubers per seed lot were tested. A field survey during the first 2 weeks of July (to avoid current season spread of PVY in fields planted with the imported seed sources) was conducted prior to the onset of aphid flights in Manitoba. Two thousand plants were observed in 10 randomly selected areas in each field, and leaves from plants showing mosaic symptoms were collected. Both seed tubers and leaves were tested, first by duplex RT-PCR described in this study, then by ELISA and bioassay for the strain identification as described below.

Serological assays. Triple antibody sandwich-ELISA was conducted to verify PVY infection and to identify strains, using three PVY MAbs recommended by NAPPO. The MAb 4C3 detects both $\mathrm{PVY}^{\mathrm{O}}$ and $\mathrm{PVY}^{\mathrm{N}}(9), \mathrm{MAb} 2$ is specific for $\mathrm{PVY}^{\mathrm{O}}$ (19), and MAb 1F5 (9) is specific for $\mathrm{PVY}^{\mathrm{N}}$. Leaf sap $(300 \mu \mathrm{l})$ from healthy plants or plants with mosaic or veinal necrosis symptoms was mixed with $300 \mu \mathrm{l}$ of extraction buffer $(20 \mathrm{mM}$ phosphate buffer, pH 7.4, $0.15 \mathrm{M} \mathrm{NaCl}, 0.05 \%$ Tween 20,
2\% polyvinyl pyrrolidone [PVP-40], 0.3\% skim milk powder) and incubated at room temperature for $3 \mathrm{~h}$. The leaf extract (100 $\mu \mathrm{l})$ was loaded in duplicate wells coated with a polyclonal PVY antibody (Phytodiagnostics Inc., Vancouver, Canada) at 1:5,000 dilution. The loaded plates were incubated at $4{ }^{\circ} \mathrm{C}$ overnight, and washed three times with double-distilled (dd) $\mathrm{H}_{2} \mathrm{O}$. Specific monoclonal antibodies were added at 1:4,000, 1:2,500, and 1:5,000 dilutions for 4C3, 1F5, and MAb2 (Phytodiagnostics Inc., Vancouver, Canada), respectively, and incubated at $37^{\circ} \mathrm{C}$ for $2.5 \mathrm{~h}$. Plates were washed three times with $\mathrm{ddH}_{2} \mathrm{O}$, and alkaline phosphatase conjugated antibodies (Jackson ImmunoResearch Laboratories, Inc., West Grove, PA) were added at 1:3,000 dilution and incubated at $37^{\circ} \mathrm{C}$ for $2.5 \mathrm{~h}$. After washing three times with $\mathrm{ddH}_{2} \mathrm{O}, 0.5 \%$ p-nitrophenyl phosphate was added to the wells and incubated at room temperature for $1 \mathrm{~h}$. The resultant absorbance at $405 \mathrm{~nm}$ was measured. The threshold for a positive reading was 0.100 if the healthy control absorbance was 0.030 or less. If the healthy control average was greater than 0.030 , then the mean of the healthy controls was multiplied by four and used as the positive threshold. The $\mathrm{PVY}^{\mathrm{O}}$-139 tobacco culture (30) was used as the positive control for $\mathrm{PVY}^{\mathrm{O}}$, while the $\mathrm{PVY}^{\mathrm{N}} \mathrm{N}-\mathrm{Jg}$ tobacco culture (24) was used as the positive control for $\mathrm{PVY}^{\mathrm{N}}$.

Bioassay. Nicotiana tabacum cv. Samsun and Solanum brachycarpum were used to determine the pathotype of PVY (29). Seedlings (three-leaf stage) of $N$. tabacum and $S$. brachycarpum grown in $15-\mathrm{cm}$ plastic pots containing a soil mix were mechanically inoculated with PVY extracts. Briefly, leaves of PVY-infected potato plants were ground with a mortar and pestle in the extraction buffer $(0.01 \mathrm{M}$ sodium phosphate, $\mathrm{pH} 7.5$, containing $0.4 \%$ sodium sulfite) (1:10, wt/vol) and mechanically inoculated to $N$. tabacum and $S$. brachycarpum for symptom expression (29). The inoculated plants were kept in the same conditions as described above. Symptoms were recorded weekly for 5 weeks.

Compositing of tuber, sprout, and leaf samples. To increase the efficiency for a large-scale survey of $\mathrm{PVY}^{\mathrm{N}: \mathrm{O}}$-like isolates in a potato crop by a duplex RT-PCR (see below), the $\mathrm{PVY}^{\mathrm{N}: \mathrm{O}}$-infected field grown tubers were used for the production of composite samples that included infected (I) and healthy $(\mathrm{H})$ materials. Infected and healthy tubers, sprouts, and leaves of three cultivars (Chieftain, Norland, and Yukon Gold) from the same seed lot were used to prepare the composites of tissues (data not shown), saps (A), and nucleic acid extracts (B). Buffered saps (see "Nucleic acid extraction") from healthy and infected sprouts or healthy and infected tubers were combined in I:H ratios of 1:10, 1:20, 1:30, $1: 40,1: 50,1: 70$, and 1:100 and used for nucleic acid extraction. The ratios were $1: 50,1: 100,1: 200,1: 400,1: 600,1: 800$, and 1:1,000 for leaf samples. The nucleic acid extracts of individual healthy and infected sample were combined to provide $\mathrm{I}: \mathrm{H}$ ratios of $1: 10,1: 50,1: 100,1: 200$, $1: 400,1: 800$, and $1: 1,200$ for tubers; $1: 10$, $1: 50,1: 100,1: 200,1: 400,1: 800,1: 1,200$, and 1:1,500 for sprouts; and 1:100, 1:500, $1: 1,500,1: 2,000,1: 2,500$, and 1:3,000 for leaf extracts. Tests with composited samples were repeated by two people and repeated five times by each person. In each test, tubers, sprouts, and leaves from three cultivars were used. Each test had three replicate samples at each $\mathrm{I}: \mathrm{H}$ ratio.

Nucleic acid extraction. Nucleic acids were extracted from leaves, tubers, and sprouts using sodium sulfite (35). For each sample, $300 \mu \mathrm{l}$ of extraction buffer $(0.1 \mathrm{M}$ Tris- $\mathrm{HCl}, \mathrm{pH} 7.4,2.5 \mathrm{mM} \mathrm{MgCl}_{2}, 0.65 \%$ $\mathrm{Na}_{2} \mathrm{SO}_{3}$, and $6 \mathrm{U}$ of DNase I) was combined with 5 drops (150 to $200 \mu \mathrm{l}$ ) of sap, obtained by a Tuber Slicer (Electrowerk, Behcke and Co., Hannover, Germany). Incubation at $37^{\circ} \mathrm{C}$ for $10 \mathrm{~min}$ was followed by extraction with an equal volume of phenol:chloroform:isoamyl alcohol $(25: 24: 1, \mathrm{vol} / \mathrm{vol} / \mathrm{vol})$ and precipitation of RNA from the aqueous phase with 1 vol of isopropanol in the presence of $0.1 \mathrm{vol}$ of 3 $\mathrm{M}$ sodium acetate $\left(-20^{\circ} \mathrm{C}\right.$, overnight). The precipitate was collected by centrifugation $\left(12,000 \times g, 15 \mathrm{~min}, 4^{\circ} \mathrm{C}\right)$, washed with $70 \%$ ethanol, dried under a vacuum, and dissolved in $1,000 \mu \mathrm{l}$ of sterile water for leaf and sprouts and $100 \mu \mathrm{l}$ for tuber samples.

RT-PCR. RNA extract $(2.5 \mu \mathrm{l}, 400 \mathrm{ng})$ plus $2.5 \mu$ l of water was incubated at $65^{\circ} \mathrm{C}$ for $8 \mathrm{~min}$ and chilled on ice for $3 \mathrm{~min}$ to denature the RNA. The RT mixture was added to provide a final concentration of $20 \mathrm{ng} / \mu \mathrm{l}$ of reverse primer (see below) (24,25): $50 \mathrm{mM}$ Tris- $\mathrm{HCl}, \mathrm{pH} \mathrm{8.3,} 75 \mathrm{mM}$ $\mathrm{KCl}, 10 \mathrm{mM}$ DTT, $2.5 \mathrm{mM} \mathrm{MgCl}_{2}, 1.5$ $\mathrm{mM}$ of each dNTPs, $20 \mathrm{U}$ RNasin (Promega Corp., Madison, WI), and $200 \mathrm{U}$ Moloney murine leukemia virus-reverse transcriptase (Gibco BRL). Samples were incubated $1 \mathrm{~h}$ at $42^{\circ} \mathrm{C}$ for RT and subsequently incubated at $95^{\circ} \mathrm{C}$ for $3 \mathrm{~min}$ to terminate the reaction.

The initial determination of PVY was carried out by a duplex method developed for PLRV and PVY (34), and the second duplex RT-PCR derived from a multiplex competitive RT-PCR (25) was used for PVY strains. It was performed using $2.0 \mu \mathrm{l}$ aliquots of the cDNA mixture in $25 \mu \mathrm{l}$ containing $10 \mathrm{mM}$ Tris- $\mathrm{HCl}, \mathrm{pH} 8.3,50$ $\mathrm{mM} \mathrm{KCl}, 1.5 \mathrm{mM} \mathrm{MgCl} 2,100 \mu \mathrm{M}$ each of dATP, dCTP, dGTP, and dTTP (Promega), $0.1 \mu \mathrm{g}$ each of the primers (reverse, 5' CATTTGTGCCCAATTGCC-3' [A]; and forward, 5'-GACAGTTGGACTTTTGCAACG-3' ${ }^{\prime}$ [S7] for an amplified product of 281 bp of PVYO ${ }^{\mathrm{O}}$ 5'-GGTGAAGCTAATCATGTCAAC-3' [S6] for an amplified product of 443 bp of $\mathrm{PVY}^{\mathrm{N} / \mathrm{NTN}}$ [25]), and 
$0.625 \mathrm{U}$ of DNA polymerase (PE Applied Biosystems, Foster City, CA). Samples were amplified for 30 cycles using a Peltier Thermal Cycler (MJ Research, Watertown, MA). Annealing temperature was $62^{\circ} \mathrm{C}$ for the first 5 cycles, $60^{\circ} \mathrm{C}$ for the next 5 cycles, $58^{\circ} \mathrm{C}$ for the following 10 cycles, and $55^{\circ} \mathrm{C}$ for the last 10 cycles. Each cycle consisted of denaturation $\left(92^{\circ} \mathrm{C}, 30 \mathrm{~s}\right)$, primer annealing (30 s) and primer extension at $72^{\circ} \mathrm{C}(90 \mathrm{~s})$, and a final products $(8 \mu \mathrm{l})$ were separated by electrophoresis in a $1.5 \%$ agarose gel containing ethidium bromide at $0.5 \mu \mathrm{g} / \mathrm{ml}$ and photographed under UV illumination with an imaging system (Alpha Innotech IS1000, San Leandro, CA).

Two cDNA clones derived from $5^{\prime}$ and $3^{\prime}$ ends of four isolates (Mb-20, Mb-23, $\mathrm{Mb}-112$, and Mb-119) from Manitoba causing tobacco veinal necrosis or mosaic symptoms were sequenced in each direction as previously described $(20,24)$ to verify the genotype of the isolates (data not shown).

\section{RESULTS} During 2000 and 2001, leaves and dormant tubers were analyzed for the presence of PVY. Combined samples $(8,812)$ of commercial and seed fields were tested by a duplex RT-PCR for PVY and PLRV (34), and 361 samples $(4.0 \%)$ were positive for PVY (Table 1, Processing and Seed combined). In seed fields, PVY incidence was $2.3 \%$, and in processing fields, the incidence was $7.7 \%$ (Table 1). Of the total 289 (Processing and Seed combined, 2000) RTPCR positive tubers in 2000, 236 germinated, and the daughter plants were used extension of $10 \mathrm{~min}$ at $72^{\circ} \mathrm{C}$. Amplified

Relative proportions of PVY strains.

for the determination of PVY strains. On the basis of symptoms expressed in the tobacco bioassay, an equal number $(50.0 \%$, 75 each) of tobacco plants had mild mosaic or veinal necrosis symptoms when the plants were inoculated with the samples from processing fields of year 2000 (Table 2). This indicates an equal proportion of $\mathrm{PVY}^{\mathrm{O}}$ and $\mathrm{PVY}^{\mathrm{N}}$-like infection in the samples collected from processing fields in that year. However, when samples collected from seed lots of year 2000 were tested, $36.0 \%(31 / 86)$ contained $\mathrm{PVY}^{\mathrm{O}}$ and $64.0 \%(55 / 86)$ had $\mathrm{PVY}^{\mathrm{N}}$-like infection (Table 2). In 2001, about one-third (6/16 and $1 / 3$ for processing and seed samples, respectively) of the PVY-positive leaves collected from processing and seed lots contained $\mathrm{PVY}^{\mathrm{O}}$, whereas two-thirds (10/16 and 2/3 for processing and seed samples, respectively) had $\mathrm{PVY}^{\mathrm{N}}$-like infection. In the tuber samples, the proportion of $\mathrm{PVY}^{\mathrm{N}}$-like infection increased dramatically, reaching over $94.1 \%$ (16/17) in the PVY-positive tubers collected from seed potatoes and $100 \%(36 / 36)$ in the processing tubers (Table 2). There was complete agreement in the tobacco bioassay and the RT-PCR results of these samples (Table 2).

A duplex RT-PCR for simultaneous detection of $P V Y^{\mathrm{O}}$ and $\mathrm{PVY}^{\mathrm{N}}$ group of strains in potato tubers and leaves. The proportion of $\mathrm{PVY}^{\mathrm{N}}$-like infection in tobacco was unexpectedly high in the population of PVY (Table 2) originating from potato samples, and this necessitated a large-scale routine testing of potato seed lots. To facilitate the simultaneous detection of $\mathrm{PVY}^{\mathrm{O}}$ and $\mathrm{PVY}^{\mathrm{N}}$-like strains in a routine indexing of potato samples, a modification of the tetraplex-competitive

Table 1. Incidence of Potato virus Y (PVY) in potato in years 2000 and 2001 in Manitoba

\begin{tabular}{lccccr}
\hline & \multicolumn{2}{c}{ Processing $^{\mathbf{a}}$} & & \multicolumn{2}{c}{ Seed $^{\mathbf{a}}$} \\
\cline { 2 - 3 } \cline { 5 - 6 } Year & No. tested & PVY & & No. tested & \multicolumn{1}{c}{ PVY } \\
\hline 2000 (tubers) & 2,277 & $175(7.7 \%)$ & & 3,924 & $114(2.9 \%)$ \\
2001 (leaves) & 67 & $16(24.0 \%)$ & & 161 & $3(1.9 \%)$ \\
2001 (tubers) & 598 & $36(6.0 \%)$ & & 1,785 & $17(1.0 \%)$ \\
Total & 2,942 & $227(7.7 \%)$ & & 5,870 & $134(2.3 \%)$ \\
\hline
\end{tabular}

${ }^{a}$ Samples were tested by a duplex reverse transcription-polymerase chain reaction for PVY and Potato leafroll virus (PLRV) (34).
RT-PCR (25) was carried out. The tetraplex-competitive RT-PCR (25) showed that the $\mathrm{PVY}^{\mathrm{N} / \mathrm{NTN}}$ from Manitoba was amplified by primers specific to Eu-type $\mathrm{PVY}^{\mathrm{N} / \mathrm{NTN}}$ (Fig. 1A, lanes 5 to 7) but not by the NA-type PVY ${ }^{\text {NTN }}$ (Fig. 1A, lane 14). Since only two strains were regularly encountered in Manitoba tuber samples, a duplex-competitive RT-PCR derived from the tetraplex PCR, using primer S6 for amplification of $\mathrm{PVY} \mathrm{Y}^{\mathrm{N} / \mathrm{NTN}}$ and $\mathrm{S} 7$ for $\mathrm{PVY}^{\mathrm{O}}$ (25), was adopted. S6 and S7, when paired with the A, resulted in a fragment of 443 bp for $\mathrm{PVY}^{\mathrm{N}}$-like strains and a fragment of 281 bp for $\mathrm{PVY}^{\mathrm{O}}$ (Fig. 1B). Analysis of tobacco plants with mosaic symptoms using duplex RT-PCR confirmed that they contained only $\mathrm{PVY}^{\mathrm{O}}$ specific PCR fragments (Fig. 1B, lanes 8, 12,15 , and 17), while those with the veinal necrotic symptoms contained PVY ${ }^{\mathrm{N} / \mathrm{NTN}_{-}}$ specific fragments (Fig. 1B, lanes 1 and 4). Differentiation of the PVYO and PVY ${ }^{\mathrm{N} / \mathrm{NTN}}$ strains on the original potato tuber and leaves was also confirmed by duplex RTPCR (data not shown). In addition, the duplex-RT-PCR of tobacco leaves showed the existence of several doubly infected $\left(\mathrm{PVY}^{\mathrm{O}}+\mathrm{PVY}^{\mathrm{N} / \mathrm{NTN}}\right.$ ) plants (Fig. 1B, lanes $2,3,5$ to 7,9 to $11,13,14,16$, and 18 to 20 ), and the virus titer based on band intensity of each strain in the doubly infected plants was variable without favoring a particular strain.

Nature of $\mathbf{P V Y}^{\mathbf{N}}$-like isolates. $S$. brachycarpum is an indicator plant in which both $\mathrm{PVY}^{\mathrm{N}}$ and $\mathrm{PVY}^{\mathrm{O}}$ strains can be differentiated by the lethal necrosis or the mosaic symptom they produce (29). When S. brachycarpum was inoculated with tobacco sap from plants used in the RT-PCR studies with mosaic or veinal necrosis symptoms (five samples of each), none of them developed lethal necrotic symptoms typical of PVY ${ }^{\mathrm{N}}$. Although both resulted in mosaic symptoms similar to $\mathrm{PVY}^{\mathrm{O}}$ in $S$. brachycarpum plants, there was an increased crinkling of the leaves inoculated with the tobacco plants with necrotic symptoms compared to those with mosaic symptoms.

When ELISA was carried out with various antibodies using tobacco leaves, the MAb 4C3 detected all samples from symp-

Table 2. Incidence of Potato virus $Y$ (PVY) strains in potato in Manitoba as determined by bioassay in tobacco and reverse transcription-polymerase chain reaction (RT-PCR)

\begin{tabular}{|c|c|c|c|c|c|c|}
\hline \multirow[b]{2}{*}{ Year } & \multicolumn{3}{|c|}{ Processing } & \multicolumn{3}{|c|}{ Seed } \\
\hline & No. tested & PVYOa & $\mathrm{PVY}^{\mathrm{Na}}$ & No. tested & PVYO & PVYN \\
\hline \multicolumn{7}{|l|}{ Bioassay } \\
\hline 2000 (tubers) & 150 & $75(50.0 \%)$ & $75(50.0 \%)$ & 86 & $31(36.0 \%)$ & $55(64.0 \%)$ \\
\hline 2001 (leaves) & 16 & $6(37.5 \%)$ & $10(62.5 \%)$ & 3 & $1(33.0 \%)$ & $2(67.0 \%)$ \\
\hline 2001 (tubers) & 36 & $0(0.0 \%)$ & $36(100.0 \%)$ & 17 & $1(5.9 \%)$ & $16(94.1 \%)$ \\
\hline \multicolumn{7}{|l|}{ RT-PCR ${ }^{b}$} \\
\hline 2000 (tubers) & 150 & $75(50.0 \%)$ & $75(50.0 \%)$ & 86 & $31(36.0 \%)$ & $55(64.0 \%)$ \\
\hline 2001 (leaves) & 16 & $6(37.5 \%)$ & $10(62.5 \%)$ & 3 & $1(33.0 \%)$ & $2(67.0 \%)$ \\
\hline 2001 (tubers) & 36 & $0(0.0 \%)$ & $36(100.0 \%)$ & 17 & $1(5.9 \%)$ & $16(94.1 \%)$ \\
\hline
\end{tabular}

a $\mathrm{PVYO}$ is the common strain of PVY; and PVYN is the tobacco veinal necrotic strain of PVY.

${ }^{\mathrm{b}}$ PVY strain specific competitive RT-PCR described in this study. 
tomatic leaves in which $A_{405}$ was significantly higher than that of healthy controls as PVY-positive (Table 3). When MAb2, the antibody specific to $\mathrm{PVY} \mathrm{Y}^{\mathrm{O}}$, was used, a high reading of $A_{405}$ was recorded for samples with symptoms, regardless of the symptom type (Table 3 ). None of the samples reacted with the $\mathrm{PVY}^{\mathrm{N}}$-specific $\mathrm{MAb}$ $1 \mathrm{~F} 5$.

To ascertain if differences at the molecular level existed in $\mathrm{PVY}^{\mathrm{N}}$-like isolates, partial nucleotide sequence of the $3^{\prime}$ and $5^{\prime}$ ends of mosaic isolates (Mb-20 and Mb23) and tobacco veinal necrotic symptom causing isolates (Mb-112 and Mb-119) was determined (data not shown). The sequences of isolates (Mb-20 and Mb-23) exhibiting mosaic symptoms were identical to that of $\mathrm{PVY}^{\mathrm{O}}$ (30) in both ends of the genome. However, sequences of the isolates (Mb-112 and Mb-119) causing tobacco veinal necrotic symptoms were similar to that of $\mathrm{PVY}^{\mathrm{O}}$ in the $3^{\prime}$ end, but different in the $5^{\prime}$ end. In fact, they were similar to Eu-PVY ${ }^{\mathrm{N} / \mathrm{NTN}}$ sequences such as PVYN -605 (GenBank accession number: $\mathrm{X} 97895$ ) in the $5^{\prime}$ end (data not shown). The isolates appeared to possess similar genomic properties to the ones reported earlier from the same area (21) (data not shown).

Absence of tuber necrosis symptoms. None of the PVY-infected samples collected from six potato cultivars (Chieftain, Norland, Russet Burbank, Russet Norkotah, Shepody, and Yukon Gold) had rings-

A

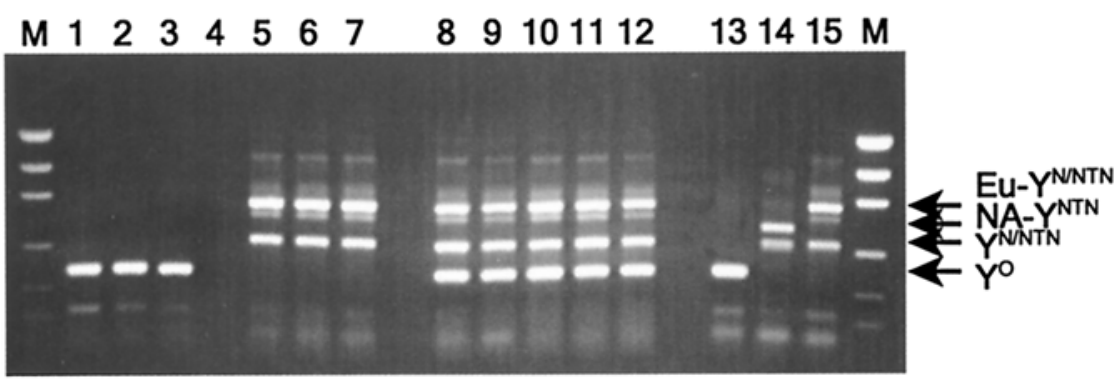

B

\section{M $12324567891011121314151617181920 M$}

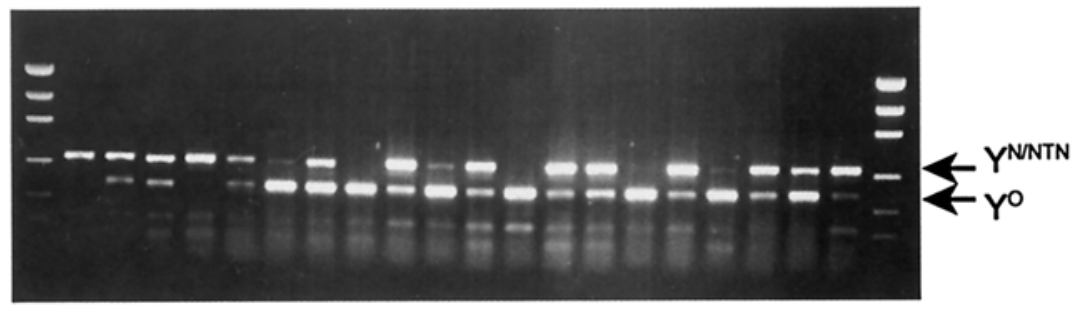

Fig. 1. A, Nucleic acid extracts from dormant tubers infected with common strain of Potato virus $Y$ $\left(\mathrm{PVY}^{\mathrm{O}}\right)$, recombinant isolate of PVY $\left(\mathrm{PVY}^{\mathrm{N}: \mathrm{O}}\right)$, or doubly infected with PVYO $+\mathrm{PVY}^{\mathrm{N}: \mathrm{O}}$ were analyzed by a multiplex (tetraplex) reverse transcription-polymerase chain reaction (RT-PCR) for their strain groups. $\mathrm{PVY}$, lanes 1 to 3,13 ; $\mathrm{PVY}^{\mathrm{N}: \mathrm{O}}$, lanes 5 to 7 ; $\mathrm{PVY}^{\mathrm{O}}+\mathrm{PVY}^{\mathrm{N}: \mathrm{O}}$, lanes 8 to 12 ; North American (NA)-PVYNTN, lane 14; European (Eu)-PVYN/NTN, lane 15; negative control, lane 4; and DNA molecular markers, lanes M. B, Nucleic acid extracts from potato tubers infected by $\mathrm{PVY}^{\mathrm{O}}$, $\mathrm{PVY}^{\mathrm{N}: \mathrm{O}}$, or PVY $\mathrm{PV}^{\mathrm{O}}+\mathrm{PVY}^{\mathrm{N}: \mathrm{O}}$ analyzed by a duplex RT-PCR. Top bands indicate PVY ${ }^{\mathrm{N} / \mathrm{NTN}}$ (all $\mathrm{PVY}^{\mathrm{N}}$-like isolates, including $\mathrm{PVY}^{\mathrm{N}: \mathrm{O}}$ ), bottom bands are $\mathrm{PVY}^{\mathrm{O}}$, and presence of two bands indicates double-infection by both strains. Lanes at both ends of gel are DNA size markers.

pot necrosis symptoms in the original field-grown tubers, or in the progenies grown in the greenhouse from the infected tubers (data not shown). Thus, these isolates that possess the coat protein region of $\mathrm{PVY}^{\mathrm{O}}$ causing veinal necrotic symptoms in tobacco similar to $\mathrm{PVY}^{\mathrm{N}}$, and that lack the ability to cause potato tuber ringspot necrosis symptoms, are different from PVYNTN. Because of the unique genomic and pathological characteristics, and to differentiate these isolates from typical PVY $Y^{\mathrm{N} / \mathrm{NTN}}$, they have been referred to as $\mathrm{PVY}^{\mathrm{N}: \mathrm{O}}$ group of isolates.

Sensitivity of $\mathrm{PVY}^{\mathrm{N}: 0}$ detection in composite samples. In the composite tuber sap samples, detection of $\mathrm{PVY}^{\mathrm{N}: \mathrm{O}}$ was unaffected by $\mathrm{I}: \mathrm{H}$ ratios up to $1: 100$ in the two cultivars (Norland and Yukon Gold) (data not shown) but it was limited to 1:50 in cv. Chieftain (Fig. 2A, lane 5). In the composites of sprout sap up to 1:100 (the highest tested) (Fig. 2A, lane 14) and in the potato leaf sap up to 1:1,000 (Fig. 2A, lane 21), $\mathrm{PVY}^{\mathrm{N}: \mathrm{O}}$ bands were observed. When extracted RNA from individual samples was used to prepare composites, the sensitivity of detection was extended to $1: 1,200$ to $1: 1,500$ in tubers and sprouts (Fig. $2 \mathrm{~B}$, lanes 1 to 7,8 to 15$)$ and over $1: 2,000$ in leaves (Fig. 2B, lanes 16 to 21). The amplified bands were more intense in the composites of sprouts in contrast to the composites of tuber sap or tuber RNA (Fig. $2 \mathrm{~A}$ and $\mathrm{B})$. RNA extracts prepared from leaves appeared to be concentrated and sometimes needed further dilution to reduce nonspecific amplifications.

Search for $\mathrm{PVY}^{\mathrm{N}: \mathrm{O}}$ strains in other potato growing areas. Most of the $\mathrm{PVY}^{\mathrm{N}: \mathrm{O}_{-}}$ infected plants developed mosaic symptoms under greenhouse conditions similar to the field symptoms of $\mathrm{PVY}^{\mathrm{O}}$-infected plants. Therefore, it appeared feasible to select potato plants on the basis of leaf symptoms during the growing season and determine the distribution of strains. In 2001, leaf sap from 1,625 leaves with mosaic symptoms from fields in New Brunswick and Prince Edward Island, inoculated to tobacco, failed to develop veinal necrotic symptoms. At the same time, 19 leaf samples with mosaic symptoms from a field known to have $\mathrm{PVY}^{\mathrm{N}: \mathrm{O}}$ infection in

Table 3. Differentiation of Potato virus $Y$ (PVY) strains in potato by a three antibody panel in enzyme-linked immunosorbent assay

\begin{tabular}{|c|c|c|c|c|c|}
\hline \multirow[b]{2}{*}{ Year } & \multicolumn{5}{|c|}{ NAPPO $^{\mathrm{a}}$-recommended monoclonal antibodies average $A_{405} \pm \mathrm{SD}$} \\
\hline & Symptoms in tobacco & No. tested & $4 \mathrm{C3}^{\mathrm{b}}(\mathrm{PVY})$ & $\mathbf{M A b 2}^{\mathbf{c}}\left(\mathbf{P V Y} \mathbf{Y}^{\mathbf{O}}\right)$ & $1 F 5^{d}\left(P^{\prime} Y^{N}\right)$ \\
\hline 2000 & Mosaic & 105 & $2.46 \pm 0.50$ & $2.83 \pm 0.50$ & $0.03 \pm 0.02$ \\
\hline 2000 & Necrosis & 130 & $1.72 \pm 0.71$ & $2.74 \pm 0.56$ & $0.02 \pm 0.04$ \\
\hline 2000 & Healthy & 50 & $0.05 \pm 0.02$ & $0.09 \pm 0.05$ & $0.02 \pm 0.02$ \\
\hline 2001 & Mosaic & 10 & $1.48 \pm 0.78$ & $2.86 \pm 0.13$ & $0.03 \pm 0.03$ \\
\hline 2001 & Necrosis & 54 & $1.90 \pm 0.48$ & $2.85 \pm 0.08$ & $0.03 \pm 0.01$ \\
\hline 2001 & Healthy & 10 & $0.02 \pm 0.01$ & $0.01 \pm 0.01$ & $0.01 \pm 0.01$ \\
\hline
\end{tabular}

a North American Plant Protection Organization.

${ }^{\mathrm{b}}$ Monoclonal antibody $4 \mathrm{C} 3$ detects both the common $\left(\mathrm{PVY}^{\mathrm{O}}\right)$ and the tobacco veinal necrotic $\left(\mathrm{PVY}^{\mathrm{N}}\right)$ strains.

${ }^{\mathrm{c}}$ Monoclonal antibody MAb2 detects $\mathrm{PVY} \mathrm{O}^{\mathrm{s}}$ strain.

${ }^{\mathrm{d}}$ Monoclonal antibody 1F5 detects $\mathrm{PVY}^{\mathrm{N}}$ strain. 
Manitoba caused mosaic symptoms in seven tobacco plants indicative of $\mathrm{PVY}^{\mathrm{O}}$ and veinal necrotic symptoms in 12 plants indicative of $\mathrm{PVY}^{\mathrm{N}: \mathrm{O}}$. This showed that not all symptomatic potato plants are infected with PVYN:O and symptoms in potato may not provide conclusive identification of this strain.

To further establish the relationship of potato seed sources with the presence of

\section{A. Sap dilution}

Tuber

Sprout

$\begin{array}{llllllll}M & 1 & 2 & 3 & 4 & 5 & 6 & 7\end{array}$

\section{B. Nucleic acid dilution}

Tuber

Sprout

Leaf

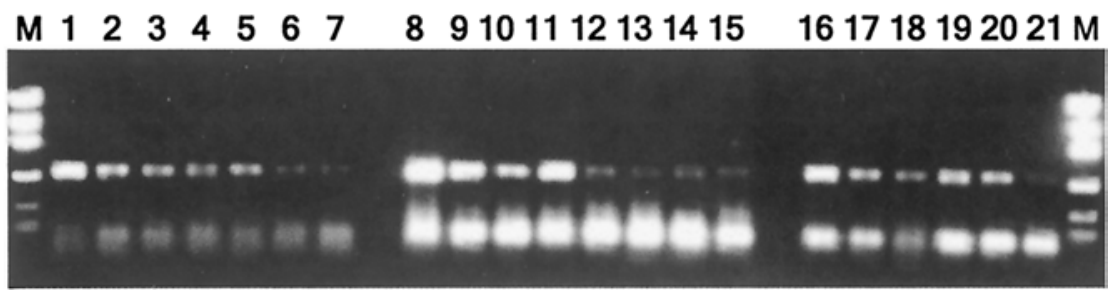

Fig. 2. Analysis of recombinant isolate of Potato virus $Y\left(\mathrm{PVY}^{\mathrm{N}: \mathrm{O}}\right)$ by reverse transcriptionpolymerase chain reaction (RT-PCR) in composite samples of tubers, sprouts, and leaves, using sap or nucleic acid extracts. A, Sap from healthy and $\mathrm{PVY}^{\mathrm{N}: \mathrm{O}}$-infected tubers were combined to provide infected:healthy $(\mathrm{I}: \mathrm{H})$ ratios of 1:10, 1:20, 1:30, 1:40, 1:50, 1:70, and 1:100 for both tubers and sprouts (lanes 1 to 7 and 8 to 14, respectively). For leaves the ratios were 1:50, 1:100, 1:200, 1:400, $1: 600,1: 800$, and 1:1,000 (lanes 15 to 21 ). B, Individual samples of nucleic acid extracts were mixed to provide I:H ratios of 1:10, 1:50, 1:100, 1:200, 1:400, 1:800, and 1:1,200 for tubers (lanes 1 to 7), and 1:10, 1:50, 1:100, 1:200, 1:400, 1:800, 1:1,200, and 1:1,500 for sprouts (lanes 8 to 15). For leaves the ratios were $1: 100,1: 500,1: 1,500,1: 2,000,1: 2,500$, and 1:3,000 (lanes 16 to 21). Lanes at both ends of gel contain molecular markers. symptomatic potato plants and the determination of $\mathrm{PVY}^{\mathrm{N}: \mathrm{O}}$ isolates from such sources, 11 imported and five local potato seed sources were tested. Of the 11 imported seed lots, four from Minnesota, Montana, and North Dakota contained $\mathrm{PVY}^{\mathrm{N}}$-like positive tubers in the duplex RT-PCR assay (Table 4, data of lots with 0 positive not shown). Leaves from plants grown from the positive tubers in the greenhouse were tested by ELISA, tobacco bioassay, and RT-PCR, which identified them as $\mathrm{PVY}^{\mathrm{N}: \mathrm{O}}$ (Table 4, right column). Leaf surveys during the growing season of the fields planted with the same seed lots corroborated the presence of infected plants with $\mathrm{PVY}^{\mathrm{N}: \mathrm{O}}$ isolates in most cases (Table 4). However, observations of symptomatic plants alone in cultivars Gold Rush, Sangre, and Viking were difficult and confirmed that symptoms in potato would not be reliable for PVY strain detection. No PVY was detected in eight other seed lots from Alberta, British Columbia, Manitoba, North Dakota, and Saskatchewan (data not shown). Of the remaining domestic seed lots from Manitoba, PVY ${ }^{\mathrm{N}: \mathrm{O}}$ was detected in four (Table 4). Again, a low infection rate based on visual symptoms in potato plants in the field planted with the same seed sources was confirmed (Table 4).

\section{DISCUSSION}

In recent years, extensive surveys for $\mathrm{PVY}^{\mathrm{N}}$ strains have been carried out in France (14), Czech Republic (26), Poland $(5,40)$, and Spain (2). Similar work has also been performed in the United States (6). These surveys have reported an increased number of recombinant isolates consisting of $\mathrm{PVY}^{\mathrm{O}}$ and $\mathrm{PVY}^{\mathrm{N}}(5,14,40)$. The group of recombinant isolates (Wilga, L-56, and L-136) cause systemic mosaic and mottle in potato leaves but no ringspot necrosis in tubers $(4,20,21)$. They are

Table 4. Determination of the recombinant isolate of Potato virus $Y\left(\mathrm{PVY}^{\mathrm{N}: \mathrm{O}}\right)$ from samples of imported and domestic potato seed sources that tested positive for PVYN in the duplex reverse transcription-polymerase chain reaction (RT-PCR) assay

\begin{tabular}{|c|c|c|c|c|c|c|c|}
\hline \multirow{2}{*}{$\begin{array}{l}\text { Potato seed } \\
\text { source }\end{array}$} & \multirow[b]{2}{*}{ Cultivar/sample } & \multirow{2}{*}{$\begin{array}{c}\text { RT-PCR } \\
\text { PVYN c }^{\mathrm{N}}\end{array}$} & \multicolumn{2}{|c|}{ ELISA $^{a}$} & \multicolumn{2}{|c|}{ Tobacco bioassay } & \multirow{2}{*}{$\begin{array}{c}\text { Conclusion }^{\text {b }} \\
\text { PVYN:O c }\end{array}$} \\
\hline & & & PVYOc & PVYN & PVYo & PVYN & \\
\hline \multirow[t]{2}{*}{ Minnesota } & Gold Rush (tubers) & 3 & 3 & 0 & 0 & 3 & 3 \\
\hline & Gold Rush (leaves) & 3 & 3 & 0 & 0 & 3 & 3 \\
\hline \multirow[t]{2}{*}{ Minnesota } & Yukon Gold (tubers) & 2 & 2 & 0 & 0 & 2 & 2 \\
\hline & Yukon Gold (leaves) & 1 & 1 & 0 & 0 & 1 & 1 \\
\hline \multirow[t]{2}{*}{ Montana } & Sangre (tubers) & 1 & 1 & 0 & 0 & 1 & 1 \\
\hline & Sangre (leaves) & 0 & 0 & 0 & 0 & 0 & 0 \\
\hline \multirow[t]{2}{*}{ North Dakota } & Gold Rush (tubers) & 2 & 2 & 0 & 0 & 2 & 2 \\
\hline & Gold Rush (leaves) & 3 & 3 & 0 & 0 & 3 & 3 \\
\hline \multirow[t]{2}{*}{ Manitoba-1 } & Shepody (tubers) & 1 & 1 & 0 & 0 & 1 & 1 \\
\hline & Shepody (leaves) & 2 & 2 & 0 & 0 & 2 & 2 \\
\hline \multirow[t]{2}{*}{ Manitoba-3 } & Russet Burbank (tubers) & 1 & 1 & 0 & 0 & 1 & 1 \\
\hline & Russet Burbank (leaves) & 0 & 0 & 0 & 0 & 0 & 0 \\
\hline \multirow[t]{2}{*}{ Manitoba-7 } & Nordonna (tubers) & 1 & 1 & 0 & 0 & 1 & 1 \\
\hline & Nordonna (leaves) & 1 & 1 & 0 & 0 & 1 & 1 \\
\hline \multirow[t]{2}{*}{ Manitoba-15 } & Russet Burbank (tubers) & 1 & 1 & 0 & 0 & 1 & 1 \\
\hline & Russet Burbank (leaves) & 7 & 7 & 0 & 0 & 7 & 7 \\
\hline
\end{tabular}

a Enzyme-linked immunosorbent assay. Antibodies used in ELISA were those stated in Table 3.

b Total number of PVYN:O in conclusion was determined by analysis of combined data of ELISA and RT-PCR.

${ }^{c} \mathrm{PVY}^{\mathrm{O}}$ is the common strain of PVY; $\mathrm{PVY}^{\mathrm{N}}$ is the tobacco veinal necrotic strain of PVY; PVY ${ }^{\mathrm{N}: \mathrm{O}}$ is the recombinant isolate of PVY. 
PVYO-like both in their $3^{\prime}$ end sequence and serology, but differ in the nucleotide sequences of the $5^{\prime}$ end of the molecule. In some cases, evolution of such recombinant isolates has been noted under controlled conditions with double-infection of $\mathrm{PVY}^{\mathrm{N}}$ and $\mathrm{PVY}^{\mathrm{O}}$ during cross-protection studies (13). These new recombinant PVY isolates (PVY ${ }^{\mathrm{N}: \mathrm{O}}-$ like) often appear to have a high multiplication and spread rate $(5,40)$ and may constitute $90 \%$ of the total $\mathrm{PVY}^{\mathrm{N}}$ population $(5,13)$. Our findings corroborate those in Europe. PVY ${ }^{\mathrm{N}: \mathrm{O}}$ isolates seem to predominate the PVY population in some fields (Table 2). There has been an increase in the proportion of recombinant isolates (as determined by serology, RT$\mathrm{PCR}$, and nucleotide sequences) in years 2000 and 2001 compared with 1996, when only two samples were detected as $\mathrm{PVY}^{\mathrm{N}: \mathrm{O}}$ from $300 \mathrm{PVY}$ samples analyzed (20). In year 2001, tuber samples contained over $90 \%$ of $\mathrm{PVY}^{\mathrm{N}: \mathrm{O}}$ strain, in contrast to roughly equal or $64 \%$ in the year 2000 (Table 2). This dramatic increase of $\mathrm{PVY}^{\mathrm{N}: \mathrm{O}}$ is of concern because of its $\mathrm{PVY}^{\mathrm{N}}$-like phenotype in tobacco plants, and thus needs reappraisal of the PVY population in every potato growing area, particularly in view of the observation that the PVY ${ }^{\text {NTN }}$ strains could have evolved as a result of high infection pressure of the $\mathrm{PVY}^{\mathrm{N}}$ isolates in one area (16). Every attempt to reduce the PVY infection pressure irrespective of straintype needs to be made to limit the formation of recombinants.

In North America and in other countries, the certification of seed tubers is subjected to virus testing using multiple antibodies. This includes a first detection of PVY by ELISA using broad-spectrum antibodies and a second test detecting $\mathrm{PVY}^{\mathrm{N}}$ using $\mathrm{PVY}^{\mathrm{N}}$-specific monoclonal antibodies (14; see the NAPPO website). As shown in the present study, the recombinant $\mathrm{PVY}^{\mathrm{N}: \mathrm{O}}$ isolates under this system would be identified as $\mathrm{PVY}^{\mathrm{O}}$ by both types of antibodies and thus may not be completely removed from a seed lot. The tolerance level of virus in various classes of seeds varies from country to country or from state to state in one country (38). Therefore, such escaped infected tubers would continue to serve as sources of virus inoculum for the aphids for the next generation. In addition, if such seed lots are exported to other areas, the recombinants would be introduced to a new region.

A limited survey of the recombinant $\left(\mathrm{PVY}^{\mathrm{N}: \mathrm{O}}\right)$ strain in this study from imported and domestic seed sources in Manitoba showed that the strain is not limited to only Manitoba. Seed tubers introduced from sources in the United States also contained PVY ${ }^{\mathrm{N}: \mathrm{O}}$ (Table 4). Therefore, distribution of this strain is much wider than we initially thought, and attempts to ensure that seed sources are free of this strain are urgently needed.
To facilitate routine detection of $\mathrm{PVY} \mathrm{Y}^{\mathrm{N}: \mathrm{O}}$ and at the same time avoid the use of multiple testing with various antibodies to determine the strain types, a multiplex (duplex) RT-PCR protocol was evaluated in this study. To minimize the cost of largescale testing of seed lots, use of the high sensitivity of RT-PCR has been made through the compositing of samples (Fig. 2). Use of dormant tubers, sprouts, or leaves can be composited, from which an indication of the presence of the $\mathrm{PVY}^{\mathrm{N}: \mathrm{O}}$ like isolates could be ascertained. Depending on the situation and the class of seed tuber, an actual percentage of individual strains present can be determined by performing tests on the individual extracts.

The recombinant isolates found in Europe have been referred to as $\mathrm{PVY}^{\mathrm{N}} \mathrm{Wi}$ or Wilga-type $(4,13)$ (named after the cultivar Wilga, in which they were first detected). These isolates are known to cause a lethal necrotic symptom in S. brachycarpum identical to PVY $\mathrm{PV}^{\mathrm{N} / \mathrm{NTN}}$ (7). However, the $\mathrm{PVY}^{\mathrm{N}: \mathrm{O}}$ isolate found in this study did not cause the lethal necrotic symptoms in S. brachycarpum; instead they caused symptoms more like PVY ${ }^{\mathrm{O}}$ (29). Thus, there is a possibility that these isolates are different from those found in Europe, and it is possible that many types of recombinants may exist with varying pathogenicity and recombination sites (10).

In conclusion, a recombinant isolate of PVY $\left(\mathrm{PVY}^{\mathrm{N}: \mathrm{O}}\right)$ was identified in Manitoba and several of the neighboring U.S. states by using strain-specific RT-PCR, ELISA, and bioassays. This isolate shares serological properties of $\mathrm{PVY}^{\mathrm{O}}$ but causes PVY ${ }^{\text {N/NTN }}$ type of symptoms in tobacco plants, and therefore could escape through the serological indexing in the seed certification program. The competitive-duplex RT-PCR was able to simultaneously differentiate between PVY ${ }^{\mathrm{O}}$ and the PVY ${ }^{\mathrm{N} / \mathrm{NTN}}$ strains including $\mathrm{PVY}^{\mathrm{N}: \mathrm{O}}$, and therefore could be used in large-scale screening and management of PVY $\mathrm{Y}^{\mathrm{N} / \mathrm{NTN}}$ in certification programs. With this in mind, further research to monitor the distribution and incidence of $\mathrm{PVY}^{\mathrm{N}: \mathrm{O}}$ and to further evaluate multiplex RT-PCR for large-scale testing of seed lots is warranted.

\section{ACKNOWLEDGMENTS}

The technical assistance of Jan Zeng, Diane Moores, and Andrea Dilworth from Potato Research Centre, Fredericton, and the summer students and technicians from Brandon Research Centre and Cavendish Farms are gratefully acknowledged.

\section{LITERATURE CITED}

1. Anon. 1991. Importation of potatoes from Canada - Rules and regulations, animal and plant health inspection service. U.S. Dep. Agric., Federal Register. Vol. 58, No. 83, April 30, 1991. pp. 19789-19791.

2. Blanco-Urgoiti, B., Tribodet, M., Leclere, S., Ponz, F., Perez de San Roman, C., Legorbwru, F. J., and Kerlan, C. 1998. Characterization of potato potyvirus Y (PVY) isolates from seed potato batches. Situation NTN, Wilga and Z isolates. Eur. J. Plant Pathol. 104:1-9.

3. Chachulska, A. M., Chrzanowska, M., Robaglia, C., and Zagorski, W. 1997. Tobacco veinal necrosis determinants are unlikely to be located within the $5^{\prime}$ and $3^{\prime}$-terminal sequences of the potato virus $\mathrm{Y}$ genome. Arch. Virol. 142:765-779.

4. Chrzanowska, M. 1991. New isolates of the necrotic strain of potato virus $\mathrm{Y}\left(\mathrm{PVY}^{\mathrm{N}}\right)$ found recently in Poland. Potato Res. 34:178182.

5. Chrzanowska, M. 2001. Importance of different strains of PVY in potato production and breeding program in Poland. Pages 12-14 in. Proc. 11th Eur. Assoc. Potato Res. Virol. Sec., Trest, Czech Republic; Ed. Potato Research Institiute, Havlíčkův Brod.

6. Crosslin, J. M., Hamm, P. B., Eastwell, K. C., Thornton, R. E., Brown, C. R., Corsini, D., Shiel, P. J., and Berger, P. H. 2002. First report of the necrotic strain of Potato virus $Y$ $\left(\mathrm{PVY}^{\mathrm{N}}\right)$ on potatoes in the northwestern United States. Plant Dis. 86:1177.

7. De Bokx, J. A., and Huttinga, H. 1981. Potato Virus Y. No. 242. AAB Commonw. Mycol. Inst./Assoc. Appl. Biol., Warwick, UK.

8. Domier, L. L., Shaw, J. G., and Rhoads, R. E. 1987. Potyviral proteins share amino acid sequence homology with picorna-, como-, and caulimoviral proteins. Virology 158:20-27.

9. Ellis, P., Stace-Smith, R., Bowler, G., and Mackenzie, D. J. 1996. Production of monoclonal antibodies for detection and identification of strains of potato virus Y. Can. J. Plant Pathol. 18:64-70.

10. Glais, L., Tribodet, M., and Kerlan, C. 2002. Genomic variability in Potato potyvirus $\mathrm{Y}$ (PVY): Evidence that PVYNW and PVYNTN variants are single to multiple recombinants between PVYO and PVYN isolates. Arch. Virol. 147:363-378.

11. Gugerli, P., and Gehringer, W. 1980. Enzymelinked immunosorbent assay (ELISA) for the detection of potato leafroll virus and potato virus $\mathrm{Y}$ in potato tubers after artificial break of dormancy. Potato Res. 23:353-359.

12. Jones, R. A. C. 1990. Strain group specific and virus specific hypersensitive reactions to infection with potyviruses in potato cultivars. Ann. Appl. Biol. 117:93-105.

13. Kaczmarek, U., and Mosakowska, E. 2001. Interaction between strains of the potato virus $\mathrm{Y}\left(\mathrm{PVY}^{\mathrm{O}}, \mathrm{PVY}^{\mathrm{N}}\right.$-type Wilga, PVY $\left.{ }^{\mathrm{NTN}}\right)$ and the potato plants of two cultivars. Pages 1820 in: Proc. 11th Eur. Assoc. Potato Res. Virol. Sec., Trest, Czech Republic; Ed. Potato Research Institiute, Havlíčkův Brod.

14. Kerlan, C., Chrzanowska, M., Glais, L., Fremondiere, G., and Tribodet, M. 2001. Biological and molecular characterization of various PVYN W isolates. Pages 1-3 in: Proc. 11th Eur. Assoc. Potato Res. Virol. Sec., Trest, Czech Republic; Ed. Potato Research Institiute, Havlíčkův Brod.

15. Kerlan, C., Tribodet, M., Glais, L., and Guillet, M. 1999. Variability of potato virus Y in potato crops in France. J. Phytopathol. 147:643-651.

16. Kus, M. 1995. The epidemic of the tuber necrotic ringspot strain of Potato virus Y $\left(\mathrm{PVY}{ }^{\mathrm{NTN}}\right)$ and its effect on potato crops in Slovenia. Pages 159-160 in: Proc. 9th Eur. Assoc. Potato Res. Virol. Sec., Bled, Slovenia; Eds. M. Rečnik, and M. Kus.

17. Le Romancer, M., Kerlan, C., and Nedellec, M. 1994. Biological characterization of various geographical isolates of potato virus $\mathrm{Y}$ inducing superficial necrosis on potato tubers. Plant Pathol. 43:138-144.

18. Marie-Jeanne Tordo, V., Chachulska, A. M., Fakhfakh, H., Le Romancer, M., Robaglia, C. and Astier-Manifacier, S. 1995. Sequence polymorphism in the $5^{\prime} \mathrm{NTR}$ and in the P1 
coding region of potato virus $\mathrm{Y}$ genomic RNA. J. Gen. Virol. 76:939-949.

19. McDonald, J. G., and Kristjansson, G. T. 1993. Properties of strains of potato virus $\mathrm{Y}^{\mathrm{N}}$ in North America. Plant Dis. 77:87-89.

20. McDonald, J. G., and Singh, R. P. 1996. Host range, symptomology and serology of isolates of potato virus $\mathrm{Y}$ (PVY) that shared properties with both the $\mathrm{PVY}^{\mathrm{N}}$ and $\mathrm{PVY} \mathrm{Y}^{\mathrm{O}}$ strain groups. Am. Potato J. 73:309-315.

21. McDonald, J. G., Wong, E., Henning, D., and Tao, T. 1997. Coat protein and $5^{\prime}$ nontranslated region of a variant of potato virus Y. Can. J. Plant Pathol. 19:138-144.

22. Nie, X., and Singh, R. P. 2000. Detection of multiple potato viruses using an oligo(dT) as a common cDNA primer in multiplex-RTPCR. J. Virol. Methods 86:179-185.

23. Nie, X., and Singh, R. P. 2001. A novel usage of random primers for multiplex RT-PCR detection of virus and viroid in aphids, leaves, and tubers. J. Virol. Methods 91:37-49.

24. Nie, X., and Singh, R. P. 2002. Probable geographical grouping of $\mathrm{PVY}^{\mathrm{N}}$ and $\mathrm{PVY} \mathrm{NTN}^{\mathrm{NTN}}$ based on sequence variation in $\mathrm{P} 1$ and $5^{\prime}$ UTR of PVY genome and methods for differentiating North American PVYNTN. J. Virol. Methods 103:145-156.

25. Nie, X., and Singh, R. P. 2002. A new approach for the simultaneous differentiation of biological and geographical strains of Potato virus $Y$ by uniplex and multiplex RT-PCR. J. Virol. Methods 104:41-54.

26. Ptáček, J., Dědič, P., and Matoušek, J. 2001. The diversification of Potato virus Y (PVY). Pages 8-11 in: Proc. 11th Eur. Assoc. Potato Res. Virol. Sec., Trest, Czech Republic; Ed. Potato Research Institiute, Havlíčkův Brod.

27. Richardson, D. E. 1958. Some observations on the potato veinal necrosis strain of potato virus Y. Plant Pathol. 7:133-135.

28. Shukla, D. D., Ward, C. W., and Brunt, A. A. 1994. The Potyviridae. Cambridge University Press, Cambridge, UK.

29. Singh, M., and Singh, R. P. 1994. A fastreacting bioassay for the tobacco veinal necrosis strain of Potato Virus Y $\left(\mathrm{PVY}^{\mathrm{N}}\right)$. Plant Dis. 78:775-778.

30. Singh, M., and Singh, R. P. 1996. Nucleotide sequence and genome organization of a Canadian isolate of the common strain of potato virus $\mathrm{Y}\left(\mathrm{PVY}^{\mathrm{O}}\right)$. Can. J. Plant Pathol. 18:209224.

31. Singh, R. P. 1992. Incidence of the tobacco veinal necrotic strain of potato virus $\mathrm{Y}$ $\left(\mathrm{PVY}^{\mathrm{N}}\right)$ in Canada in 1990 and 1991 and scientific basis for eradication of the disease. Can. Plant Dis. Surv. 72:113-119.

32. Singh, R. P. 1998. Reverse-transcription polymerase chain reaction for the detection of viruses from plants and aphids. J. Virol. Methods 74:125-138.

33. Singh, R. P., Boucher, A., Somerville, T. H., and Dhar, A. K. 1993. Selection of a monoclonal antibody to detect $\mathrm{PVY}^{\mathrm{N}}$ and its use in ELISA and DIBA assays. Can. J. Plant Pathol. 15:293-300.

34. Singh, R. P., Kurz, J., and Bioteau, G. 1996. Detection of stylet-borne and circulative potato viruses in aphids by duplex reverse transcription polymerase chain reaction. J. Virol. Methods 59:189-196.

35. Singh, R. P., Nie, X., Singh, M., Coffin, R. and Duplessis, P. 2002. Sodium sulphite inhibition of potato and cherry polyphenolics in nucleic acid extraction for virus detection by RT-PCR. J. Virol. Methods 99:123-131.

36. Singh, R. P., Singh, M., and McDonald, J. G.
1998. Screening by a 3-primer PCR of North American $\mathrm{PVY}^{\mathrm{N}}$ isolates for European-type members of the tuber necrosis-inducing PVY ${ }^{\text {NTN }}$ subgroup. Can. J. Plant Pathol. 20:227-233.

37. Singh, R. P., and Somerville, T. H. 1986 Factors affecting the detection of potato virus $\mathrm{Y}$ in tubers by enzyme-linked immunosorbent assay (ELISA). Indian J. Plant Pathol. 4:9197.

38. Slack, S. A., and Singh, R. P. 1998. Control of viruses affecting potatoes through seed potato certification programs. Pages 249-260 in: Plant Virus Disease Control. A. Hadidi, R. K Khetarpal, and H. Koganezawa, eds. American Phytopathological Society, St. Paul, MN.

39. Smith, K. M., and Dennis, R. W. G. 1940 Some notes on a suspected variant of $\mathrm{So}$ lanum virus 2 (potato virus Y). Ann. Appl. Biol. 27:65-70

40. Turska, E., and Daczmarek, U. 2001. Occurrence of the Potato virus Y strains (PVY) during long-term multiplication of some potato cultivars in Poland. Pages 21-24 in: Proc. 11 th Eur. Assoc. Potato Res. Virol. Sec., Trest, Czech Republic; Ed. Potato Research Institiute, Havlíčkův Brod.

41. Walsh, K., North, J., Barker, I., and Boonham, N. 2001. Detection of different strains of Potato virus $\mathrm{Y}$ and their mixed infections using competitive fluorescent RT-PCR. J. Virol. Methods 91:167-173.

42. Weidemann, H. L. 1988. Importance and control of potato virus $\mathrm{YN}\left(\mathrm{PVY}^{\mathrm{N}}\right)$ in seed potato production. Potato Res. 31:85-94

43. Weilguny, H., and Singh, R. P. 1998. Separation of Slovenian isolates of PVYNTN from North American isolates of $\mathrm{PVY}^{\mathrm{N}}$ by a 3primer PCR. J. Virol. Methods 71:57-68. 